\title{
COMMENTARY
}

\section{Reflections of a First-Generation College Student, American, and Academician}

\author{
Frank Romanelli, PharmD, MPH ${ }^{\mathrm{a}, \mathrm{b}}$ \\ ${ }^{a}$ University of Kentucky, College of Pharmacy, Lexington, Kentucky \\ ${ }^{\mathrm{b}}$ Executive Associate Editor, American Journal of Pharmaceutical Education, Arlington, Virginia
}

Submitted January 30, 2020; accepted February 3, 2020; published August 2020.

The Higher Education Act of 1965 and 1998 defined a first-generation college student as "a student both of whose parents did not complete a bachelor's degree, or in the case of students who live with and are supported by only one parent, a student whose only such parent did not complete a bachelor's degree." " As of 2016, of the 7.3 million undergraduates attending four-year public and private colleges and universities, about $24 \%$ are firstgeneration college students (FGCS). ${ }^{2}$ The majority of FGCS are White (46\%), followed by Hispanic or Latin (25\%), and then Black or African American (18\%) and Asian (6\%). An estimated $50 \%$ of FGCS are from lowincome families with a median parental income of approximately $\$ 41,000$. Discussions centered on FGCS and their hardships and successes have become commonplace on most college campuses. Almost every academic institution has begun maintaining analytics on this group.

I quite honestly never gave much deliberate thought to my status as a first-generation student while in pharmacy school. My parents did not speak much English, and Italian was their and my first language. My parents immigrated to the United States in the 1960s, more specifically, 1963 or as my mom still refers to it "the year President Kennedy was shot." Neither of my parents progressed beyond the fifth grade in school, meaning their math and language skills were severely limited. As I sit through academic meetings and conferences where this topic is discussed, I often think about my experiences and how my status as a first-generation American and college student shaped my time in pharmacy school and now as a faculty member and administrator.

Growing up in an immigrant household was complicated and arduous. For as long as I can remember, both my parents left the house for work six days a week before the sun came up. My father also regularly accepted masonry side jobs to raise extra money. Their early mornings

Corresponding Author: Frank Romanelli, University of Kentucky, College of Pharmacy, 789 South Limestone Rd., Lexington, KY 40536. Tel: 859-257-4778. Email:

froma2@uky.edu became my early mornings. Being appropriately dressed and fed meant getting up as early as they did. Sleeping in was rarely an option. Since both parents worked until at least 4:00 PM, my afternoon "latchkey kid" ritual from the age of nine involved using my own house key, figuring out my own homework, and fixing my own snack. While Italian was my first language, English came quickly as most new languages do to young children. I grew up without a home computer of any kind or even a microwave. Our stereo was probably the most high-tech piece of equipment in our home. Only recently did I purchase a smart phone for my parents, and they are still laboring to completely understand how it works. I always recognized that I was somehow dissimilar from my peers, but unlike many other children of immigrants, there was no obvious physical way to differentiate me from the majority of other kids. But there were other markers. I remember having "European sandals" long before they were fashionable, and a typical lunch was an oversized mortadella sandwich on Italian bread. I did not experience my first peanut butter and jelly sandwich or even a s'more until I was a pharmacy resident. In hindsight, I realize I suffered from what was probably an early form of impostor syndrome or at least some condition that involved developing two identities: one for home and one for school. In academic settings, I was always wondering if I had done enough to fit in. Trying to fit in often meant trying not to be noticed or at least not noticed as different. This maneuvering can require a great deal of energy that might otherwise be used on more productive tasks directly related to scholastic success. Also, with more recent recognition of wellness as an issue for today's college students, the Academy should consider the potential added stress and stressors that are faced by first-generation students who are attempting to navigate the uniqueness of both their upbringing and life on campus. ${ }^{3}$

My parents were industrious and prudent with their resources, only ever opening credit card accounts when they were well into their fifties and it became all but necessary to purchase certain things, including airline 


\section{American Journal of Pharmaceutical Education 2020; 84 (8) Article 8007.}

tickets. We certainly never went without any necessities but despite their best efforts, there was a constant fear of not having enough or of some eminent threat (eg, an injury on the job, a downturn in the economy, a layoff). While these fears can reside in the minds of just about any family, they are likely incrementally more tangible among immigrant families who rely on the consistent availability of blue-collar jobs to make ends meet and the prospects of navigating unemployment with a poor grasp of English is extremely daunting. To immigrants' perceptions of a safety net and other protections are that more fragile and less likely to be taken for granted. The college application process was particularly daunting in terms of navigating and understanding admissions requirements, selecting schools with affordable tuition rates, and sorting through financial aid. My parents were not able to provide much assistance in this regard. In fact, in an odd retrograde way, I typically had to wade through the information and then explain it to my parents. While I attended a private, Catholic, college preparatory high school that provided some financial assistance, the constant fear of appearing ignorant sometimes imposed a barrier to asking for help. I faced other steep challenges, such as finding affordable room and board and opening a checking account.

The first-generation experience also came with some advantages. My parents understood the value of education and imparted that understanding to me from as far back as I can remember. Working blue-collar jobs for eight-plus hours a day, often six days a week, ingrained in my parents the value-added proposition of a college education. I never considered not going to college. It was not an option as far as my parents were concerned. As education and schooling was so valued by my family, so too were the conduits of that commodity: teachers. My parents insisted that I have respect for my teachers. Even when teachers were wrong, they were right. It was fruitless to blame an instructor for a poor grade or an unfair assignment or a perception of biased treatment in the classroom. I also watched my parents struggle with seemingly simple activities of normal life that for most people are afterthoughts, like visiting the department of motor vehicles, filling out a job application, or scheduling a doctor visit. I learned at a very early age to decipher medical bills, insurance letters, and other official correspondences that my parents could not easily interpret. Through all this, my parents were driven and determined. They persisted, and from observing them, I gained grit.

When I was considering whether to attend pharmacy school, my parents were particularly supportive. They were raised in a small farming village in Southern Italy with limited local access to medical care. The pharmacist within the village was a revered and essential professional who functioned as a therapist, compounder, dispenser, and sometimes prescriber. The pharmacist also stocked and sold various chemicals and potions used in processing, preserving, and curing meats and in making cheeses. The pharmacist was highly regarded; thus, it was easy for my parents and extended family to understand why I decided to become a pharmacist and to support me in all aspects of that endeavor. Explaining my decision to pursue residency training after my pharmacy degree, however, was met with confusion not unlike that encountered by most students choosing this path, whether or not they are FGCS. Even more confusing was the prospect of electing to complete residency training at a distance, which typically requires air travel. First-generation students are likely to come from families that are accustomed to high levels of interdependence, which relies on the proximity of the nuclear family. Guilt may come from physically distancing themselves from their core family and potentially being accused of abandonment. Students may feel real or perceived pressure to remain physically bound to their nuclear family. This has been termed by some as "break away guilt" and can place significant stress on students that must now cast ever wider nets in terms of residencies and residency locations. ${ }^{4}$ These factors can influence a student's decision to pursue residency training as well as influence the location of programs they consider. Additionally, and interrelated to success, students may feel guilt associated with experiencing upward mobility in terms of societal status.

In reflecting upon the manner and environment of my upbringing, I cannot help but think it has impacted how I learned and now how I function as a faculty member and administrator. I wonder why the thought of tracking first-generation students was not previously considered and whether that was appropriate. Additionally, I wonder about the experiences of a first-generation student in 2020. I would think that the internet boom and social media age has made things both easier and simultaneously more difficult for immigrants in general. The volume of information available and the rapidity of access to that data is remarkable but potentially imposing. The wealth of information is only of value if it can be accessed and access requires both possession of newer technological devices and the savviness to operate and navigate them.

I had never really considered if anyone would really be interested in my status as a first-generation student and American. Most would probably never guess that I was the child of immigrants, but it does make for a fun fact to share during icebreaker games. Many colleges and schools have begun to proactively identify faculty members and administrators who are first-generation students 


\section{American Journal of Pharmaceutical Education 2020; 84 (8) Article 8007.}

and make them and their stories available to those who are seeking similar mentors and/or role models. First-generation students may experience unique challenges in both applying to and completing pharmacy school. These trials can be compounded by the current nature of pharmacy as a profession and by the rigors of pharmacy curricula and training. Given the circumstances of many first-generation students, the prospects of failure are likely more significant and the pressure to succeed more daunting. Interestingly, the curriculum quality surveys conducted by the American Association of Colleges of Pharmacy do not track first-generation status of either students or faculty members. It may be prudent for the Academy to pay more attention to first-generation students and their experiences within our institutions. Recognizing the power of personal narratives, it may also be logical for more faculty members within our Academy who are first-generation students and/or Americans to share their stories.

\section{REFERENCES}

1. Higher Education Act of 1965, 1998 Higher Education Act Amendments Subpart 2-Federal Early Outreach and Student Services Programs. https://www2.ed.gov/about/offices/list/ope/trio/ triohea.pdf. Accessed July 22, 2020.

2. First Generation College Students Demographic Characteristics and Postsecondary Enrollment. US Department of Education, National Center for Education Statistics. https://firstgen.naspa.org/ files/dmfile/FactSheet-01.pdf. Accessed July 22, 2020.

3. Canning EA, LaCosse J, Kroeper KM, et al. Feeling like an imposter: the effect of perceived classroom competition on the daily psychological experiences of first-generation college students. Social Psychological and Personality Science. 2019; https://doi.org/ 10.1177/1948550619882032.

4. London HB. Breaking away: a study of first-generation college students and their families. American Journal of Education. 1989;97:144-170. 